\title{
Increased BRCA1 protein in mammary tumours of rats fed marine $\omega-3$ fatty acids
}

\author{
MARIE-LISE JOURDAN ${ }^{1}$, KARINE MAHÉO $^{1}$, AURÉLIA BARASCU ${ }^{1}$, CAROLINE GOUPILLE $^{1}$, \\ MONIQUE PEFFAULT DE LATOUR ${ }^{2}$, PHILIPPE BOUGNOUX ${ }^{1}$ and PASCALE G. RIO ${ }^{3}$
}

\author{
${ }^{1}$ INSERM, E 0211; Université François Rabelais; CHU Bretonneau, Tours, F-37000; ${ }^{2}$ Centre Jean Perrin, Laboratoire \\ d'Anatomopathologie, Clermont-Ferrand, F-63011; ${ }^{3}$ INSERM, U484, Clermont-Ferrand, F-63005; Université \\ Clermont 1, Clermont-Ferrand, F-63000; Centre Jean Perrin, Clermont-Ferrand, F-63011, France
}

Received September 5, 2006; Accepted November 13, 2006

\begin{abstract}
Any factor affecting BRCA gene regulation may be of interest in the prevention of breast tumourigenesis. We studied the influence of dietary docosahexaenoic acid (DHA), a major $\omega-3$ fatty acid present in marine products, on rat autochthonous mammary tumourigenesis. DHAsupplementation significantly reduced the incidence of tumours $(30 \%, \mathrm{P}=0.007)$ and led to a $60 \%$ increase $(\mathrm{P}=0.02)$ in BRCA1 protein level. Since DHA influences the product of a major tumour suppressor gene, this finding may contribute to the observation that high-fish consumption reduces the risk of breast cancer.
\end{abstract}

\section{Introduction}

Differences in breast cancer incidence rates between countries and changes in the incidence of breast cancer among migrant populations have led to focus on the role of dietary factors in breast cancer risk $(1,2)$. Several epidemiological studies have suggested that dietary habits including high-fish consumption may decrease the risk of breast cancer (3-8). Analysis of biomarkers of food consumption have individualized docosahexaenoic acid (DHA: 22:6n-3), a major constituent of marine food as protective against breast cancer $(9,10)$. In rodents, long chain $\omega-3$ polyunsaturated fatty acids (PUFA) reduce mammary tumourigenesis in both induced or transplanted mammary tumour experimental systems (11-14). However, drawing conclusions from nutritional experiments is difficult because dietary lipids are generally provided as a mixture of several different fatty acids and not as individual fatty acids. The effect of a high $\omega-3$ PUFA diet on tumour growth is dependent on the $\omega-6 / \omega-3$ PUFA ratio $(11,15-18)$.

Correspondence to: Dr P.G. Rio, INSERM, U484, rue Montalembert, BP184, Clermont-Ferrand, F-63005, France

E-mail: rio@inserm484.u-clermont1.fr

Key words: BRCA1, mammary tumours, $\omega-3$ fatty acids
Interactions between PUFA and other constituents such as the dietary oxidative status $(19,20)$ should also be considered.

Beside dietary environment, genetic factors such as alterations in BRCA1/2 tumour suppressor genes play a major role in the risk of developing breast or ovarian cancer $(21,22)$. Although the precise biochemical activities of BRCA are still unknown, roles in transcriptional regulation, cell-cycle checkpoint control and DNA damage repair have been described (23). In parallel to genetic predisposition to breast and ovarian cancers, BRCA1 has also been reported to be underexpressed in a subset of sporadic breast cancers (24-26), indicating that any factor affecting the regulation of its expression could influence breast tumourigenesis. Fatty acids have already been described as such candidates. BRCA1 protein interacts with acetyl-CoA carboxylase, an enzyme of fatty acid biosynthesis (27) and its cellular localization is modified by inhibition of fatty acid synthase activity (28). Furthermore, DHA increases BRCA1/2 transcription in several human breast cancer cell lines (29). To determine whether these cell line-derived observations have an in vivo relevance, we used the same model of rat mammary tumours as in previous studies $(30,31)$. In contrast to transplanted tumours, this model provides autochthonous tumours which are similar to the human disease. In these conditions, we studied the influence of a diet enriched in DHA on BRCA1/2 expression in mammary tumours.

\section{Materials and methods}

Animals. A total number of 36 pathogen-free female SpragueDawley rats were purchased sequentially from Iffa-Credo (L'Asbresle, France) when they were 40 days of age. The care of these animals was in accordance with institution guidelines. They were housed three per cage and maintained at constant temperature and humidity $\left(22^{\circ} \mathrm{C}\right)$ with a 12 -h light/ dark cycle. All rats were fed a general purpose breeding and rearing diet (Harlan Teklad TRM Rat/Mouse Diet, France).

Diets. Animals were fed a basal diet containing $7 \%$ of a mixture of oils. This mixture (one third of rapeseed oil and two thirds of peanut oil) was designed to ensure that there were no dramatic differences in any fatty acid except for DHA (22:6n-3), and to prevent essential fatty acid deficiencies, 
Table I. Fatty acid composition of the final oil mixture in the control or DHA-supplemented diets.

\begin{tabular}{lcc}
\hline & \multicolumn{2}{c}{ Diets (\%) } \\
\cline { 2 - 3 } $\begin{array}{l}\text { Fatty acids } \\
\text { \% of peak area) }\end{array}$ & Control & DHA-supplemented \\
\hline Saturates & & \\
14:0 & 1.1 & 7.7 \\
$16: 0$ & 22.5 & 13.9 \\
$18: 0$ & 3.3 & 1.9 \\
Total $^{\mathrm{a}}$ & 27.7 & 24.1 \\
Monounsaturates $_{18: 1 \mathrm{n}-9 \mathrm{c}}$ & & \\
Total & & \\
n-6 PUFA & 44.0 & 36.9 \\
18:2n-6c & & 38.2 \\
Total & & \\
n-3 PUFA & 14.0 & 10.5 \\
18:3n-3 & 14.1 & 10.6 \\
22:6n-3 & & \\
Total & 1.5 & 21.6 \\
\hline
\end{tabular}

ancluding 20:0. ' Including 16:1, 20:1, 22:1 and 24:1. 'Including 18:3n-6.

such as linoleic acid (18:2n-6) or $\alpha$-linolenic acid (18:3n-3). The composition of the basal diet included casein, $22 \mathrm{~g} / 100 \mathrm{~g}$; methionine, $0.16 \mathrm{~g} / 100 \mathrm{~g}$; corn starch, $37.3 \mathrm{~g} / 100 \mathrm{~g}$; sugar, $18.7 \mathrm{~g} / 100 \mathrm{~g}$; cellulose, $2 \mathrm{~g} / 100 \mathrm{~g}$; minerals, $4 \mathrm{~g} / 100 \mathrm{~g}$; vitamins $\mathrm{A}, \mathrm{D}_{3}, \mathrm{~K}_{1}, \mathrm{~B}_{1}, \mathrm{~B}_{5-9}, \mathrm{~B}_{12}$ and $\mathrm{C}, 1 \mathrm{~g} / 100 \mathrm{~g}$. This basal diet was supplemented with $8 \%$ additional lipids: control group (18 rats) was supplemented with palm oil (graciously provided by Société Industrielle des Oléagineux, St. Laurent Blangy, France), DHA group (18 rats) with DHASCO oil (40\% DHA; graciously provided by Martek Inc., Columbia, MD, USA). Each diet (mixture of oils and basal diet) was analyzed for fatty acids (Table I). In the control and DHA groups, respectively, the saturates, monounsaturates and 18:2n-6 did not differ markedly. Among n-3 PUFA, $\alpha$-linolenic acid was identical between both groups, while DHA reached $21.4 \%$ in the intervention group, versus $1.6 \%$ in the control group. Thus, in the two dietary groups, the final composition of the oil mixture did not differ greatly except for DHA. These diets were given two days after initiation and throughout all the experimental time (17 weeks) up to the sacrifice of the animals, in accordance with institution guidelines. All animals were fed ad libitum ( $25 \mathrm{~g} / \mathrm{rat} / \mathrm{day})$ and were weighed weekly. No statistical difference in body weights was observed between the dietary groups during the experiment.

Experimental carcinogenesis. At 47 days of age, the rats received a single dose of $\mathrm{N}$-Nitroso- $\mathrm{N}$-methylurea (NMU, Sigma, France) by a subcutaneous injection $(25 \mathrm{mg} / \mathrm{kg}$ body weight) as previously described (20). Each animal was palpated weekly beginning three weeks after the injection of NMU to determine the location, latency, incidence and multiplicity of NMU-induced tumours. Latency was assessed as the delay of the first tumour appearance (in weeks) per rat. Incidence corresponded to the percentage of tumour-bearing rats and multiplicity to the number of tumours per tumour-bearing rat. At the end of the experiment (17 weeks), animals were sacrificed and necropsied. Adipose and tumour tissues were harvested, rinsed in saline buffer, weighed and immediately frozen and kept in liquid nitrogen for biochemical analysis.

Cell cycle analysis. Proliferating fraction was assessed by measuring the distribution of cells within the cell cycle by flow cytometry after staining of DNA with propidium iodide (Coulter DNA-prep reagent), as previously described (20). DNA content analysis was performed on a Coulter Epics Elite ESP flow cytometer (Beckman Coulter, Villepinte, France). DNA index (DI) and cell cycle distribution were calculated with the Multicycle Advanced Software (Phoenix Flow Systems, San Diego, CA).

Tissue lipids analysis. Determination of the fatty acid content of the adipose and tumour tissues was carried out as described previously (32). Briefly, after lipid extraction (33), triglycerides (for the adipose tissue) and phospholipids (for the tumour tissue) were purified by silica gel thin layer chromatography with hexane/diethyl ether/acetic acid (70:30:1, v:v:v). Lipids were dissolved in $2 \mathrm{ml} 14 \%$ boron trifluoride in methanol (plus $1.6 \mathrm{ml}$ hexane and $4.4 \mathrm{ml}$ methanol for triglycerides) and transesterified at $100^{\circ} \mathrm{C}$. Fatty acid methyl esters were separated by gas chromatography (GC Trace, ThermoFinnigan, Les Ulis, France). The column was $60 \mathrm{~m}$ long, with a $0.25-\mathrm{mm}$ internal diameter and a $0.25-\mu \mathrm{m}$ thickness BPX70 phase (SGE, Courtaboeuf, France). Fatty acids were identified by comparing their retention times with those of authenticated fatty acids. Results were expressed as percent of total chromatogram peak area.

Quantification of BRCAl/2 proteins. Total tissue proteins were labelled with ${ }^{125}$ iodine (Amersham Biosciences, Saclay, France) as previously described (25). Glycoproteins were recovered from an affinity chromatography onto a lentil-lectin Sepharose column (Amersham Biosciences). The level of glycoproteins was controlled to be unaffected by the diet. BRCA1 and BRCA2 proteins were detected by immunoprecipitation with rabbit polyclonal antibodies (H100, H300 respectively; Santa Cruz Biotechnology, CA) followed by affinity-perfusion chromatography onto a Poros-Protein A column of a BioCad Sprint system (Applied Biosystems, ZA Courtabœuf, France). The amount of BRCA proteins was expressed as a percentage of total glycoproteins: percentage of eluted radioactivity in the assay with specific antibodies - percentage of eluted radioactivity in the control without specific antibodies. Each quantification was made in triplicate.

RNA quantification. The quantification of BRCA1 and BRCA2 mRNAs was performed by real-time quantitative PCR with the 18S rRNA as reference gene as described $(29,34)$. 18S rRNA was previously controlled to be unaffected by diets. Total- 
Table II. Fatty acid composition of rat adipose (triglycerides) and tumour (phospholipids) tissues.

\begin{tabular}{|c|c|c|c|c|}
\hline \multirow[b]{2}{*}{ Fatty acids } & \multicolumn{2}{|c|}{ Adipose tissue } & \multicolumn{2}{|c|}{ Tumour tissue } \\
\hline & Control & DHA-supplemented & Control & DHA-supplemented \\
\hline \multicolumn{5}{|l|}{ Saturates } \\
\hline 14:0 & $1.0 \pm 0.1$ & $4.9 \pm 0.3^{\mathrm{d}}$ & $0.6 \pm 0.1$ & $0.8 \pm 0.0^{\mathrm{d}}$ \\
\hline 16:0 & $24.9 \pm 0.6$ & $21.6 \pm 1.0^{\mathrm{d}}$ & $25.2 \pm 0.7$ & $26.0 \pm 1.5$ \\
\hline 18:0 & $2.6 \pm 0.3$ & $3.3 \pm 1.0$ & $16.3 \pm 2.2$ & $14.9 \pm 1.8$ \\
\hline Total $^{\mathrm{a}}$ & $28.9 \pm 0.6$ & $30.3 \pm 1.9$ & $44.9 \pm 2.2$ & $45.2 \pm 3.6$ \\
\hline \multicolumn{5}{|c|}{ Monounsaturates } \\
\hline $16: 1$ & $3.6 \pm 0.4$ & $3.2 \pm 0.8$ & $0.7 \pm 0.1$ & $1.1 \pm 0.1^{\mathrm{d}}$ \\
\hline $18: 1 n-9$ & $52.2 \pm 1.2$ & $44.8 \pm 2.3^{\mathrm{d}}$ & $12.5 \pm 2.5$ & $14.5 \pm 2.8$ \\
\hline Total $^{\mathrm{b}}$ & $56.4 \pm 1.3$ & $48.6 \pm 1.9^{\mathrm{d}}$ & $13.9 \pm 2.7$ & $17.6 \pm 3.0$ \\
\hline \multicolumn{5}{|l|}{ n-6 PUFA } \\
\hline $18: 2 n-6 c$ & $12.1 \pm 0.4$ & $11.2 \pm 0.5^{\mathrm{d}}$ & $2.7 \pm 0.4$ & $5.4 \pm 0.3^{\mathrm{d}}$ \\
\hline $20: 3 n-6$ & trace & trace & $0.5 \pm 0.0$ & $1.2 \pm 0.5^{\mathrm{d}}$ \\
\hline $20: 4 n-6$ & $0.2 \pm 0.0$ & $0.0 \pm 0.0^{\mathrm{d}}$ & $17.2 \pm 1.2$ & $8.5 \pm 0.6^{\mathrm{d}}$ \\
\hline Total $^{c}$ & $12.6 \pm 0.4$ & $11.4 \pm 0.5^{\mathrm{d}}$ & $22.6 \pm 1.2$ & $16.2 \pm 0.6^{\mathrm{d}}$ \\
\hline \multicolumn{5}{|l|}{ n-3 PUFA } \\
\hline $18: 3 n-3$ & $0.6 \pm 0.0$ & $0.8 \pm 0.0^{\mathrm{d}}$ & trace & trace \\
\hline $20: 5 n-3$ & trace & $0.2 \pm 0.0^{\mathrm{d}}$ & $0.1 \pm 0.0$ & $1.4 \pm 0.5^{\mathrm{d}}$ \\
\hline $22: 5 n-3$ & trace & $0.2 \pm 0.0^{\mathrm{d}}$ & $0.2 \pm 0.1$ & $0.8 \pm 0.3^{\mathrm{d}}$ \\
\hline $22: 6 n-3$ & $0.1 \pm 0.0$ & $6.6 \pm 0.7^{\mathrm{d}}$ & $1.7 \pm 0.3$ & $3.9 \pm 0.9^{\mathrm{d}}$ \\
\hline Total & $0.7 \pm 0.1$ & $7.9 \pm 0.7^{\mathrm{d}}$ & $2.0 \pm 0.4$ & $6.1 \pm 1.8^{\mathrm{d}}$ \\
\hline
\end{tabular}

ancluding 12:0, 13:0, 15:0, 17:0, 20:0, 21:0, 22:0, 23:0, 24:0. 'Including 14:1, 15:1, 17:1, 20:1, 22:1 and 24:1. 'Including 18:2n-6t, 18:3n-6, 20:2n-6 and 22:2n-6. Values are expressed as mean percentage $(\%)$ of peak area \pm SD $(n=4)$ and compared with the Mann-Whitney nonparametric test. ${ }^{\mathrm{d}}$ Differences were considered significant at $\mathrm{P} \leq 0.05$.

RNAs, extracted with the RNA4PCR kit (Ambion, Huntingdon, UK), were reverse transcribed using the Ready-to-go You prime kit (Amersham Biosciences). Real-time quantitative PCR based on TaqMan chemistry was carried out with an ABI PRISM 7700 SDS analytical thermal cycler (Applied Biosystems). Using the comparative CT method (CT: cycle threshold value), the amount of mRNAs was expressed as $\Delta \mathrm{C}_{\mathrm{T}}\left(\mathrm{C}_{\mathrm{T}} \mathrm{BRCA}-\mathrm{C}_{\mathrm{T}} 18 \mathrm{~S}\right.$ rRNA). Each sample was assayed in triplicate.

Statistical analysis. Statistical analysis was performed using the GraphPad Prism program (GraphPad Software Inc., San Diego CA). The incidences obtained in the different dietary groups were compared with the $\chi^{2}$ test. Other parameters were compared with the Mann-Whitney non-parametric test. Differences were considered significant at $\mathrm{P} \leq 0.05$.

\section{Results}

Table II shows that the fatty acid profile was altered in adipose and in tumour tissues from rats in the DHA-supplemented group as compared with controls. In adipose tissue, the DHA content was much greater in the DHA-supplemented group than in the control group (66-fold, $\mathrm{P}<0.0001)$. This major increase in DHA led to an increase in other n-3 PUFA and a decrease in most fatty acids of the other classes. In tumour tissue, there was a 2.3-fold increase in DHA and also an increase in eicosapentaenoic acid (EPA, 20:5n-3). There was also a 2-fold decrease in arachidonic acid (AA, 20:4n-6). Monounsaturated and saturated fatty acids remained essentially unchanged.

Fig. 1a shows a typical macroscopic aspect of mammary autochthonous tumours at sacrifice, with typical irregular and budding features. Other presentations were also observed including necrotic or haemorrhagic areas. All mammary tumours were qualified as carcinoma by the pathologist. A typical aspect of carcinoma with papillary differentiation is shown in Fig. 1b. There was no difference in the macroscopic presentation or in the pathological aspect among the two dietary groups. The distribution of tumour cells within the cell cycle is presented in Fig. 1c. The S-phase fraction, indicative of the proliferation state, was uniformly low $(\sim 4 \%)$ and was unaffected by diet (Fig. 1d).

The effect of this dietary intervention on carcinogenesis parameters is presented in Table III. There was a 30\% decrease in the tumour incidence in the DHA-supplemented group 


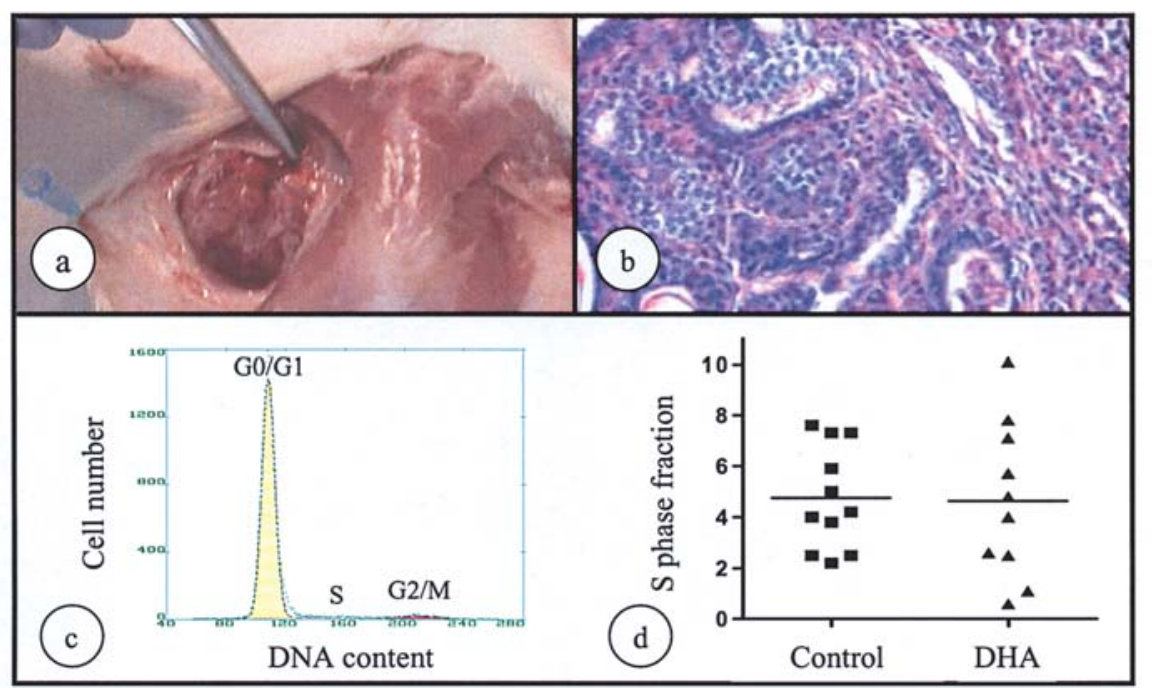

Figure 1. Characteristics of autochthonous mammary tumours induced in female rats. (a) Macroscopical aspect; (b) histological presentation (x125); (c) distribution of cells within the cell cycle; (d) S phase fraction according to the diet.

Table III. Effect of dietary DHA on mammary carcinogenesis in rats.

\begin{tabular}{lccc}
\hline & Control & DHA-supplemented & P-value \\
\hline Incidence (\%) & 100 & 67 & 0.007 \\
Latency (weeks) & $8.8 \pm 1.0$ & $8.9 \pm 1.3$ & $\mathrm{~ns}$ \\
Multiplicity & $2.8 \pm 0.3$ & $2.3 \pm 0.3$ & $\mathrm{~ns}$ \\
Tumour mass (mg) & $343 \pm 72$ & $289 \pm 102$ & $\mathrm{~ns}$ \\
\hline
\end{tabular}

Incidence corresponds to the percentage of tumour-bearing rats. Latency is the delay of the first tumour appearance per rat (in weeks). Multiplicity is the number of tumours per tumour-bearing rat. Tumour mass is the mean of tumour mass per tumour-bearing rats. The incidences in the different dietary groups were compared with the $\chi^{2}$ test. Other parameters were expressed as mean \pm SEM and compared with the Mann-Whitney non-parametric test. ns, non significant.

when compared to the control. Latency, multiplicity and tumour mass were not affected.

As seen in Fig. 2a, BRCA1/2 mRNA quantities $\left(\Delta \mathrm{C}_{\mathrm{T}}\right)$ were not significantly different among tumours from rats fed a DHA-enriched diet as compared with the control (BRCA1: $10.44 \pm 2.85$ vs. $11.24 \pm 3.28$ ) (BRCA2: $10.39 \pm 4.03$ vs . $9.61 \pm 4.15)$. The BRCA1 protein level was increased by $60 \%$ in tumours from rats fed the DHA diet as compared with the control $(\mathrm{P}=0.02)$. The BRCA2 protein level was also higher although the difference was not significant (Fig. 2b).

\section{Discussion}

We report that supplementation of diet with DHA leads to an increased amount of BRCA1 protein along with a decreased incidence of autochthonous mammary tumours in rats. Since the risk of breast cancer is known to be increased by a lack of BRCA1 protein function, our findings suggest that BRCA1 up-regulation by DHA might account for the observation that high-fish consumption is protective against the risk of breast cancer.

In our model, a sustained supplementation by DHA led to marked changes in tissue fatty acid compositions. These changes differed among adipose tissue taken as an indicator of stored fatty acids and tumour tissue. In adipose tissue, a major increase in DHA content was compensated by changes in most lipid classes. In contrast, in tumour tissue, the increase in n-3 fatty acids was accounted for by a small increase in DHA (2.3-fold) and a much stronger increase in EPA, indicating a retro-conversion activity from DHA to EPA as already reported in humans (35). Among n-6 PUFA, AA was decreased 2-fold while linoleic acid (18:2n-6) was increased 2-fold, suggesting an inhibition of the elongation desaturation pathways. These observations indicate that dietary DHA is non-specifically stored in the adipose tissue whereas in the tumour tissue, its accumulation in membrane phospholipids is associated with specific modifications of the metabolic pathways, possibly interacting with different gene products such as BRCA1. Thus, EPA could also play a role in the BRCA1 up-regulation and variations in $\omega-6 / \omega-3$ ratio should not be excluded, either.

The fact that only the incidence rate was decreased in the DHA-supplemented group fits the hypothesis that the antitumour effect of DHA occurs early in carcinogenesis. This is supported by the absence of changes in S-phase fraction, which suggests that DHA did not affect cell proliferation. It is noteworthy that in breast cancer cell lines, proliferation is unaffected by a moderate 2.4-fold induction of BRCA1 (36). Accordingly, it is not surprising that no difference in the anatomo-pathological aspect of the tumours was detectable among the two dietary groups. No DNA-aneuploidy was found within tumour tissues contrary to what is observed in humans (37). This observation seems to be specific to NMUinduced mammary tumours and has already been made under other nutritional conditions (20).

The DHA-enriched diet led to an up-regulation of BRCA1 protein in mammary tumours without any change in BRCA1 mRNA level, indicating a translational or post-translational 

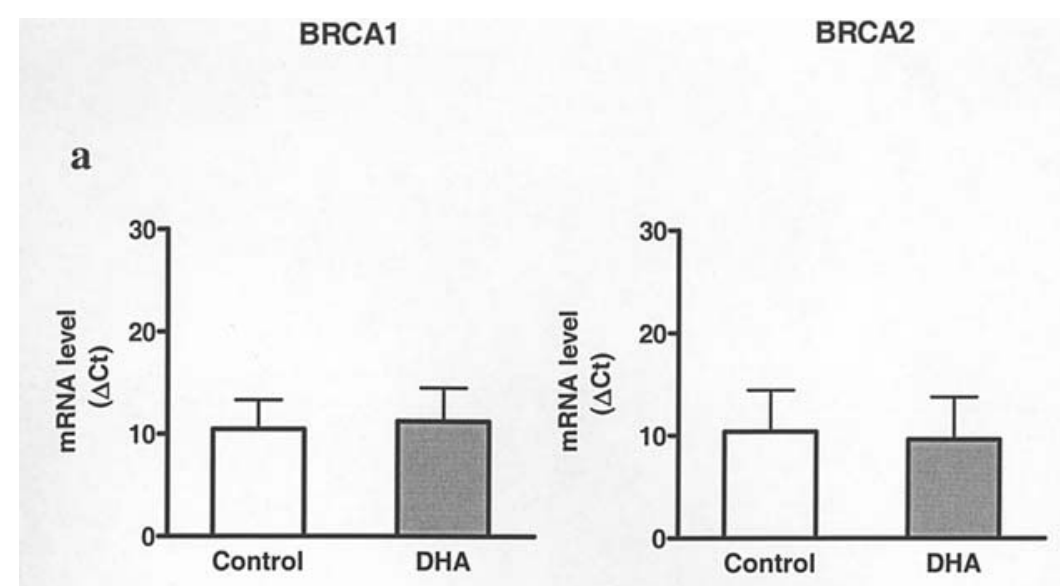

b
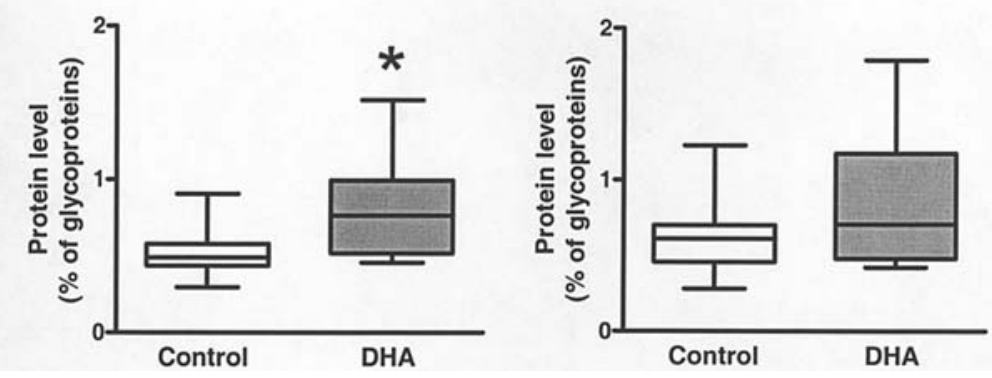

Figure 2. Expression of BRCA1 and BRCA2 mRNAs and proteins in tumour tissues of rats according to the diet. Tumours were sampled at the time of sacrifice. (A) BRCA mRNAs were analysed by real-time quantative RT-PCR and (B) proteins by immunoprecipitation followed by affinity-perfusion chromatography. Data represent mean values $\pm \mathrm{SD}$ of three independent assays. *Significant difference $(\mathrm{P}<0.05$; Mann-Whitney test).

regulation of BRCA1 by DHA. However, a transcriptional regulation cannot be excluded since the probe, located on exons 6 and 7 junction, is common to the predominant fulllength transcript and to only one of the two minor spliced forms identified in rat mammary glands (38). This up-regulation of BRCA1 protein is the first described in vivo. In humans, BRCA1 protein and mRNA levels have been reported to be decreased in some human sporadic breast tumours when compared to non-tumour breast tissues, as a consequence either of loss of heterozygosity of the BRCA1 locus (39) or promoter methylation (40-43). In contrast to BRCA1, BRCA2 may be overexpressed in human sporadic tumours $(44,45)$. There is no evidence for epigenetic silencing by hypermethylation of the BRCA2 promoter in human breast cancer (46) but BRCA2 inactivation by EMSY, a protein inhibiting BRCA2 transcriptional activity, has recently been described (47). Such different types of regulation between BRCA1 and BRCA2 could account for the differential effect of DHA observed on expression of BRCA1 and BRCA2 proteins.

Very little information is available in the literature regarding $\omega-3$ fatty acid exposure and BRCA regulation in breast cancer cell lines. Only two studies addressed this issue; one did not find an increase in mRNA while the other did $(29,48)$. In these experiments, no data involving membrane fatty acids of cells were available, thus making any interpretation highly speculative. It should be stressed that the fatty acid effect varies greatly, depending on experimental conditions such as cell density, serum percentage, and type of fatty acid as reviewed by Diggle (49). Even if cell cultures are far from the in vivo situation, we previously found, as circumstantial evidence, that the order of magnitude of DHA increase was similar in membrane phospholipids of breast cancer cells and rat tumours in our experimental conditions $(50,51)$. Membrane DHA enrichment in cell lines was associated with an increase of lipid peroxidation (51) and an inhibition of proliferation (50). BRCA1 has also been known to be involved in repair of DNA oxidative lesions $(52,53)$ or in induction of cell cycle arrest and apoptosis in cases of excessive DNA damage (54). Since DHA, a long chain polyunsaturated fatty acid, is highly peroxidizable, BRCA1 protein overexpression may result from the oxidative damage to cell macromolecules. Whether BRCA1 participates in these molecular pathways remains to be investigated.

Although the contribution of diet to the risk of breast cancer is now widely acknowledged, the multiple possible mechanisms are only starting to be deciphered (55). Our study linking one major tumour suppressor gene associated with hereditary predisposition to breast cancer to key nutritional factors involved in the incidence rate of this cancer opens up perspectives for dietary prevention in breast cancer.

\section{Acknowledgements}

This study was supported in part by grants from Ligue Nationale contre le Cancer, by Institut National de la Santé et de la Recherche Médicale (INSERM: Action Thématique Concertée 'Nutrition'). DHASCO oil was generously supplied by Martek Inc. 


\section{References}

1. Doll R: The lessons of life: keynote address to the nutrition and cancer conference. Cancer Res 52: S2024-S2029, 1992.

2. Kolonel LN, Altshuler D and Henderson BE: The multiethnic cohort study: exploring genes, lifestyle and cancer risk. Nat Rev Cancer 4: 519-527, 2004.

3. Kaizer L, Boyd NF, Kriukov V and Tritchler D: Fish consumption and breast cancer risk: an ecological study. Nutr Cancer 12: 61-68, 1989.

4. Vatten LJ, Bjerve KS, Andersen A and Jellum E: Polyunsaturated fatty acids in serum phospholipids and risk of breast cancer: a case-control study from the Janus serum bank in Norway. Eur J Cancer 29A: 532-538, 1993.

5. Landa MC, Frago N and Tres A: Diet and the risk of breast cancer in Spain. Eur J Cancer Prev 3: 313-320, 1994.

6. Caygill CP and Hill MJ: Fish, n-3 fatty acids and human colorectal and breast cancer mortality. Eur J Cancer Prev 4: 329-332, 1995.

7. Franceschi S, Favero A, La Vecchia C, Negri E, Dal Maso L, Salvini S, Decarli A and Giacosa A: Influence of food groups and food diversity on breast cancer risk in Italy. Int J Cancer 63: 785-789, 1995.

8. Hirose K, Tajima K, Hamajima N, Inoue M, Takezaki T, Kuroishi T, Yoshida M and Tokudome S: A large-scale, hospitalbased case-control study of risk factors of breast cancer according to menopausal status. Jpn J Cancer Res 86: 146-154, 1995.

9. Zhu ZR, Agren J, Mannisto S, Pietinen P, Eskelinen M, Syrjanen K and Uusitupa M: Fatty acid composition of breast adipose tissue in breast cancer patients and in patients with benign breast disease. Nutr Cancer 24: 151-160, 1995.

10. Maillard V, Bougnoux P, Ferrari P, Jourdan ML, Pinault M, Lavillonniere F, Body G, Le Floch O and Chajes V: N-3 and N-6 fatty acids in breast adipose tissue and relative risk of breast cancer in a case-control study in Tours, France. Int J Cancer 98: 78-83, 2002.

11. Cohen LA, Chen-Backlund JY, Sepkovic DW and Sugie S Effect of varying proportions of dietary menhaden and corn oil on experimental rat mammary tumor promotion. Lipids 28 : 449-456, 1993

12. Cave WT Jr: Omega-3 polyunsaturated fatty acids in rodent models of breast cancer. Breast Cancer Res Treat 46: 239-246, 1997.

13. Noguchi M, Minami M, Yagasaki R, Kinoshita K, Earashi M, Kitagawa H, Taniya T and Miyazaki I: Chemoprevention of DMBA-induced mammary carcinogenesis in rats by low-dose EPA and DHA. Br J Cancer 75: 348-353, 1997.

14. Yuri T, Danbara N, Tsujita-Kyutoku M, Fukunaga K, Takada H, Inoue $\mathrm{Y}$, Hada $\mathrm{T}$ and Tsubura A: Dietary docosahexaenoic acid suppresses N-methyl-N-nitrosourea-induced mammary carcinogenesis in rats more effectively than eicosapentaenoic acid. Nutr Cancer 45: 211-217, 2003

15. Sasaki T, Kobayashi Y, Shimizu J, Wada M, In'nami S, Kanke Y and Takita T: Effects of dietary n-3-to-n-6 polyunsaturated fatty acid ratio on mammary carcinogenesis in rats. Nutr Cancer 30: 137-143, 1998 .

16. Chajes V and Bougnoux P: Omega-6/omega-3 polyunsaturated fatty acid ratio and cancer. World Rev Nutr Diet 92: 133-151, 2003.

17. Bougnoux P, Giraudeau B and Couet C: Diet, cancer and the lipidome. Cancer Epidemiol Biomarkers Prev 15: 416-421, 2006.

18. Olivo SE and Hilakivi-Clarke L: Opposing effects of prepubertal low- and high-fat n-3 polyunsaturated fatty acid diets on rat mammary tumorigenesis. Carcinogenesis 26: 1563-1572, 2005.

19. Gonzalez MJ, Schemmel RA, Dugan L Jr, Gray JI and Welsch CW: Dietary fish oil inhibits human breast carcinoma growth: a function of increased lipid peroxidation. Lipids 28 : 827-832, 1993

20. Cognault S, Jourdan ML, Germain E, Pitavy R, Morel E, Durand G, Bougnoux P and Lhuillery C: Effect of an alphalinolenic acid-rich diet on rat mammary tumor growth depends on the dietary oxidative status. Nutr Cancer 36: 33-41, 2000.

21. King MC, Marks JH and Mandell JB: Breast and ovarian cancer risks due to inherited mutations in BRCA1 and BRCA2. Science 302: 643-646, 2003.

22. Levy-Lahad E and Plon SE: Cancer. A risky business - assessing breast cancer risk. Science 302: 574-575, 2003.

23. Narod SA and Foulkes WD: BRCA1 and BRCA2: 1994 and beyond. Nat Rev Cancer 4: 665-676, 2004.
24. Thompson ME, Jensen RA, Obermiller PS, Page DL and Holt JT Decreased expression of BRCA1 accelerates growth and is often present during sporadic breast cancer progression. Nat Genet 9: 444-450, 1995 .

25. Rio PG, Maurizis JC, Peffault de Latour M, Bignon YJ and Bernard-Gallon DJ: Quantification of BRCA1 protein in sporadic breast carcinoma with or without loss of heterozygosity of the BRCA1 gene. Int J Cancer 80: 823-826, 1999.

26. Wilson CA, Ramos L, Villasenor MR, Anders KH, Press MF, Clarke K, Karlan B, Chen JJ, Scully R, Livingston D, Zuch RH, Kanter MH, Cohen S, Calzone FJ and Slamon DJ: Localization of human BRCA1 and its loss in high-grade, non-inherited breast carcinomas. Nat Genet 21: 236-240, 1999.

27. Magnard C, Bachelier R, Vincent A, Jaquinod M, Kieffer S, Lenoir GM and Venezia ND: BRCA1 interacts with acetyl-CoA carboxylase through its tandem of BRCT domains. Oncogene 21: 6729-6739, 2002

28. Menendez JA, Mehmi I, Atlas E, Colomer R and Lupu R: Novel signaling molecules implicated in tumor-associated fatty acid synthase-dependent breast cancer cell proliferation and survival: role of exogenous dietary fatty acids, p53-p21WAF1/CIP1, ERK1/2 MAPK, p27KIP1, BRCA1 and NF-kappaB. Int J Oncol 24: 591-608, 2004.

29. Bernard-Gallon DJ, Vissac-Sabatier C, Antoine-Vincent D, Rio PG, Maurizis JC, Fustier P and Bignon YJ: Differential effects of n-3 and n-6 polyunsaturated fatty acids on BRCA1 and BRCA2 gene expression in breast cell lines. Br J Nutr 87: 281-289, 2002

30. Germain E, Lavandier F, Chajes V, Schubnel V, Bonnet P, Lhuillery $C$ and Bougnoux P: Dietary n-3 polyunsaturated fatty acids and oxidants increase rat mammary tumor sensitivity to epirubicin without change in cardiac toxicity. Lipids 34 (suppl): S203, 1999

31. Colas S, Paon L, Denis F, Prat M, Louisot P, Hoinard C, Le Floch O, Ogilvie G and Bougnoux P: Enhanced radiosensitivity of rat autochthonous mammary tumors by dietary docosahexaenoic acid. Int J Cancer 109: 449-454, 2004.

32. Bougnoux P, Koscielny S, Chajes V, Descamps P, Couet C and Calais G: alpha-linolenic acid content of adipose breast tissue: a host determinant of the risk of early metastasis in breast cancer. Br J Cancer 70: 330-334, 1994

33. Bligh EG and Dyer WJ: A rapid method of total lipid extraction and purification. Can J Biochem Physiol 37: 911-917, 1959.

34. Vissac-Sabatier C, Coxam V, Dechelotte P, Picherit C, Horcajada MN, Davicco MJ, Lebecque P, Bignon YJ and Bernard-Gallon D: Phytoestrogen-rich diets modulate expression of Brca1 and Brca2 tumor suppressor genes in mammary glands of female Wistar rats. Cancer Res 63: 6607-6612, 2003.

35. Von Schacky C and Weber PC: Metabolism and effects on platelet function of the purified eicosapentaenoic and docosahexaenoic acids in humans. J Clin Invest 76: 2446-2450, 1985.

36. Welcsh PL, Lee MK, Gonzalez-Hernandez RM, Black DJ, Mahadevappa M, Swisher EM, Warrington JA and King MC: BRCA1 transcriptionally regulates genes involved in breast tumorigenesis. Proc Natl Acad Sci USA 99: 7560-7565, 2002.

37. Chassevent A, Jourdan ML, Romain S, Descotes F, Colonna M, Martin PM, Bolla M and Spyratos F: S-phase fraction and DNA ploidy in 633 T1T2 breast cancers: a standardized flow cytometric study. Clin Cancer Res 7: 909-917, 2001.

38. Bennett LM, Brownlee HA, Hagavik S and Wiseman RW: Sequence analysis of the rat Brca1 homolog and its promoter region. Mamm Genome 10: 19-25, 1999.

39. Staff S, Isola J and Tanner M: Haplo-insufficiency of BRCA1 in sporadic breast cancer. Cancer Res 63: 4978-4983, 2003.

40. Dobrovic A and Simpfendorfer D: Methylation of the BRCA1 gene in sporadic breast cancer. Cancer Res 57: 3347-3350, 1997.

41. Rice JC, Massey-Brown KS and Futscher BW: Aberrant methylation of the BRCA1 $\mathrm{CpG}$ island promoter is associated with decreased BRCA1 mRNA in sporadic breast cancer cells. Oncogene 17: 1807-1812, 1998.

42. Esteller M, Silva JM, Dominguez G, Bonilla F, Matias-Guiu X, Lerma E, Bussaglia E, Prat J, Harkes IC, Repasky EA, Gabrielson E, Schutte M, Baylin SB and Herman JG: Promoter hypermethylation and BRCA1 inactivation in sporadic breast and ovarian tumors. J Natl Cancer Inst 92: 564-569, 2000.

43. Catteau A and Morris JR: BRCA1 methylation: a significant role in tumour development? Semin Cancer Biol 12: 359-371, 2002.

44. Bieche I, Nogues C and Lidereau R: Overexpression of BRCA2 gene in sporadic breast tumours. Oncogene 18: 5232-5238, 1999. 
45. Egawa C, Miyoshi Y, Taguchi T, Tamaki Y and Noguchi S: High BRCA2 mRNA expression predicts poor prognosis in breast cancer patients. Int J Cancer 98: 879-882, 2002.

46. Collins N, Wooster R and Stratton MR: Absence of methylation of $\mathrm{CpG}$ dinucleotides within the promoter of the breast cancer susceptibility gene BRCA2 in normal tissues and in breast and ovarian cancers. Br J Cancer 76: 1150-1156, 1997.

47. Hughes-Davies L, Huntsman D, Ruas M, Fuks F, Bye J, Chin SF, Milner J, Brown LA, Hsu F, Gilks B, Nielsen T, Schulzer M, Chia S, Ragaz J, Cahn A, Linger L, Ozdag H, Cattaneo E, Jordanova ES, Schuuring E, Yu DS, Venkitaraman A, Ponder B, Doherty A, Aparicio S, Bentley D, Theillet C, Ponting CP, Caldas $\mathrm{C}$ and Kouzarides T: EMSY links the BRCA2 pathway to sporadic breast and ovarian cancer. Cell 115: 523-535, 2003.

48. Kachhap SK, Dange PP, Santani RH, Sawant SS and Ghosh SN: Effect of omega-3 fatty acid (docosahexanoic acid) on BRCA1 gene expression and growth in MCF-7 cell line. Cancer Biother Radiopharm 16: 257-263, 2001.

49. Diggle CP: In vitro studies on the relationship between polyunsaturated fatty acids and cancer: tumour or tissue specific effects? Prog Lipid Res 41: 240-253, 2002.

50. Barascu A, Besson P, Le Floch O, Bougnoux P and Jourdan ML: CDK1-cyclin B1 mediates the inhibition of proliferation induced by omega-3 fatty acids in MDA-MB-231 breast cancer cells. Int J Biochem Cell Biol 38: 196-208, 2006.
51. Maheo K, Vibet S, Steghens JP, Dartigeas C, Lehman M, Bougnoux P and Gore J: Differential sensitization of cancer cells to doxorubicin by DHA: A role for lipoperoxidation. Free Radic Biol Med 39: 742-751, 2005.

52. Le Page F, Randrianarison V, Marot D, Cabannes J, Perricaudet M, Feunteun J and Sarasin A: BRCA1 and BRCA2 are necessary for the transcription-coupled repair of the oxidative 8-oxoguanine lesion in human cells. Cancer Res 60: 5548-5552, 2000 .

53. Gilmore PM, Quinn JE, Mullan PB, Andrews HN, McCabe N, Carty M, Kennedy RD and Harkin DP: Role played by BRCA1 in regulating the cellular response to stress. Biochem Soc Trans 31: 257-262, 2003.

54. Yoshida K and Miki Y: Role of BRCA1 and BRCA2 as regulators of DNA repair, transcription and cell cycle in response to DNA damage. Cancer Sci 95: 866-871, 2004.

55. World Cancer Research Fund: Food, Nutrition and the Prevention of Cancer: A Global Perspective. Potter JD (ed). American Institute for Cancer Research, Banta Book Group, Washington DC, 1997. 